\title{
Intimate Connections: Political Interests and Group Activity in State and Local Parties
}

\author{
Denise L. Baer and Julie A. Dolan, The American University
}

Using data from the 1988 Party Elite Study, this paper tests two different models of how interests and parties are related among a national sample of state and local party leaders and activists. Two models of interest intermediation are compared: the pluralist model stressing consensus and bipartisanship, and the party government model stressing conflict and partisanship. New research is reviewed suggesting that political interests have become nationalized and work within the parties. Using Stinchcombe's "crucial experiment," opposing assumptions of the two models are compared. While we do not test whether interests and parties are equally strong, we do find that strong parties and strong interests share a complementary, even intimate relationship. Strong support is found for the pervasiveness of interests among party elites, the presence of distinct party-linked ideological differences between group members and non-members, linkage between interest membership and organized party factions, group structuring of political information and communication, and a group consciousness. Based on these findings, we find support for the advent of true factions in the contemporary party system, and the conflict model of partisan intermediation in the post-reform party system is confirmed. The fact that interests are so strongly intertwined with the state and local parties provides disconfirmation of the pervasive myth that strong interests lead to decline at the grassroots.

Data are inconvenient. They interfere with one's theory. Time and again . . we we devised clever explanations . . only to find that important parts of the data did not fit. This is disheartening. Some of us vowed to forswear data collection in the future. . . . For the present, however, we are stuck with our data, and we are therefore obliged to deal with them (Heinz, Laumann, Nelson and Salisbury 1993, xiii).

What is the relationship between parties and interests? The dictum accepted by most interest group scholars is that "when parties are weak, interest groups are strong" (Petracca 1992, 22). Since we know from a variety of studies of interest groups that there are "more of them and [they are] more active" (Mundo 1992, 8), it would seem an obvious deduction that parties must be weakened. Some scholars (e.g., Cigler and Loomis 1991, 20) even have gone so far as to argue that the decline of parties has resulted in increased interest group strength. The presumption that parties at the state and local level or the national level are now weak or weaker than they were

Denise L. BAER is a Visiting Associate Professor of American Government at The American University.

JULIE A. DOLAN works for the Women's Campaign Fund and is a doctoral candidate at The American University.

The American Review of Politics, Vol. 15, Summer, 1994: 257-289

${ }^{\top} 1994$ The American Review of Politics 
in 1960 has been refuted by various researchers (Baer 1993; Eldersveld 1986; Cotter, Gibson, Bibby and Huckshorn 1984; Crotty 1986; Herrnson 1990). If so, we are left with a paradox: interest group "theory" tells us that strong parties and strong interests cannot co-exist. Yet they do. In this paper, we critically examine this paradox by comparing different models of interest intermediation using a national probability sample of party leaders-the 1988 wave of the Party Elite Study.

\section{The Relation of Interests to Parties}

If "data are inconvenient," it is because we demand that our theories account for them. The central area of disagreement between party and interest group scholars concerning the health of parties focuses on the latter's robustness at the grassroots-a key tenet of pluralism (Baer and Bositis 1988). While party organizations as mere administrative apparati may be indisputably stronger, pluralist critics fear that the ability of local parties to sustain grassroots activity has declined to the point that "the two major parties [are] closer to becoming mass organizations themselves" (Hayes $1983,122)$. Understood within the framework of pluralist theorists, it is argued that the national party and nationally based interests have increased in power at the expense of more localized sources of influence (Banfield $1980,26)$.

Nelson Polsby has concluded that groups organized on a communal or face-to-face basis have been undermined- "in particular, the groups traditionally served by city machines, geographically compact and ethnically homogeneous neighborhood groups" $(1983,154)$. Using V.O. Key's (1950) critique of floating personality-based factions in the one-party South, Polsby (1983) has bemoaned what he calls the loss of "peer review" where party leaders and interest group leaders were central in screening potential candidates while group members were largely inactive in politics and buffered by cross-cutting memberships. Now, group members and party activists in conjunction with their leaders play a dominant role. Restorationist critics of reform view the new "mass" groups showing high levels of member involvement in the national parties as "artificial," in contrast to local face-to-face groups (Baer and Bositis 1988).

The theory of pluralism was formulated in the post-World War II era and predates the contemporary transformation of interest groups. Is the consensus-based pluralist theory bound by the fairly unique characteristics of the 1950 s political system ${ }^{1}$ Today there are not only more interests, but there are also new types of interests (e.g., social movements, citizens groups) with different policy agendas and new repertoires of political 
action-including protests, grassroots lobbying by constituents, and electioneering in which groups seek to elect members of their own group to office (Browning, Marshall, and Tabb 1990). This mobilization of new interests through new channels has led to counter-mobilization among traditional interests-what Duverger called "contagion from the left."

Increasingly, interest group scholars (e.g., Thurber 1991; Berry 1989, 1993) have concluded that this new environment of interests has dramatically expanded the scope of conflict. Based on the assumption that ordinary citizens are not naturally interested in politics, the consensus-based theory of pluralism provides little explanation for conflict other than a dangerous degeneration into mass society. By comparison, party scholar E.E. Schattschneider's (1960) conflict theory views expanded conflict (i.e., the "socialization of conflict") as desirable in a democratic society because it progressively engages citizens in politics. Schattschneider was a critic of pluralism because he stressed the primacy of parties, yet he viewed interests as the essential "raw materials of politics." There were two key issues for Schattschneider: first, there be must be diversity of interests so that large interests cannot always dominate and collude to shut out less powerful interests; second, these interests competed openly on a national level, rather than privately on a local level (the "privatization of conflict"). Thus, Schattschneider's conflict theory of party government would predict an intimate relationship between strong interests and strong parties (Baer 1993).

\section{Interest and Partisan Intermediation: Four Strategies}

Have local parties have been left by the wayside in this "advocacy explosion" (as pluralists predict), or do interests and parties work in tandem (as party theorists would predict)? The party government theory and pluralist theory each provide opposing models or paradigms of how interest groups can participate outside of the party system, compared to models of conflict and mobilization through parties (see Figure 1).

Pluralism assumes that group leaders bargain, lobby and negotiate in politics, while group members remain inactive beyond group social activities. The essence of classic or direct lobbying is its use of bipartisan strategies to obtain desired legal and administrative changes. Direct lobbying of politicians focuses on government officials based on their strategic position in the decision-making process for that issue, not their partisan affiliation. By employing the classic "Insider" lobbying model, interest groups seek influence by establishing close personal contacts between their leaders and select government players. Insider lobbyists come from the same background as members of Congress (indeed, many are former congressmembers or 

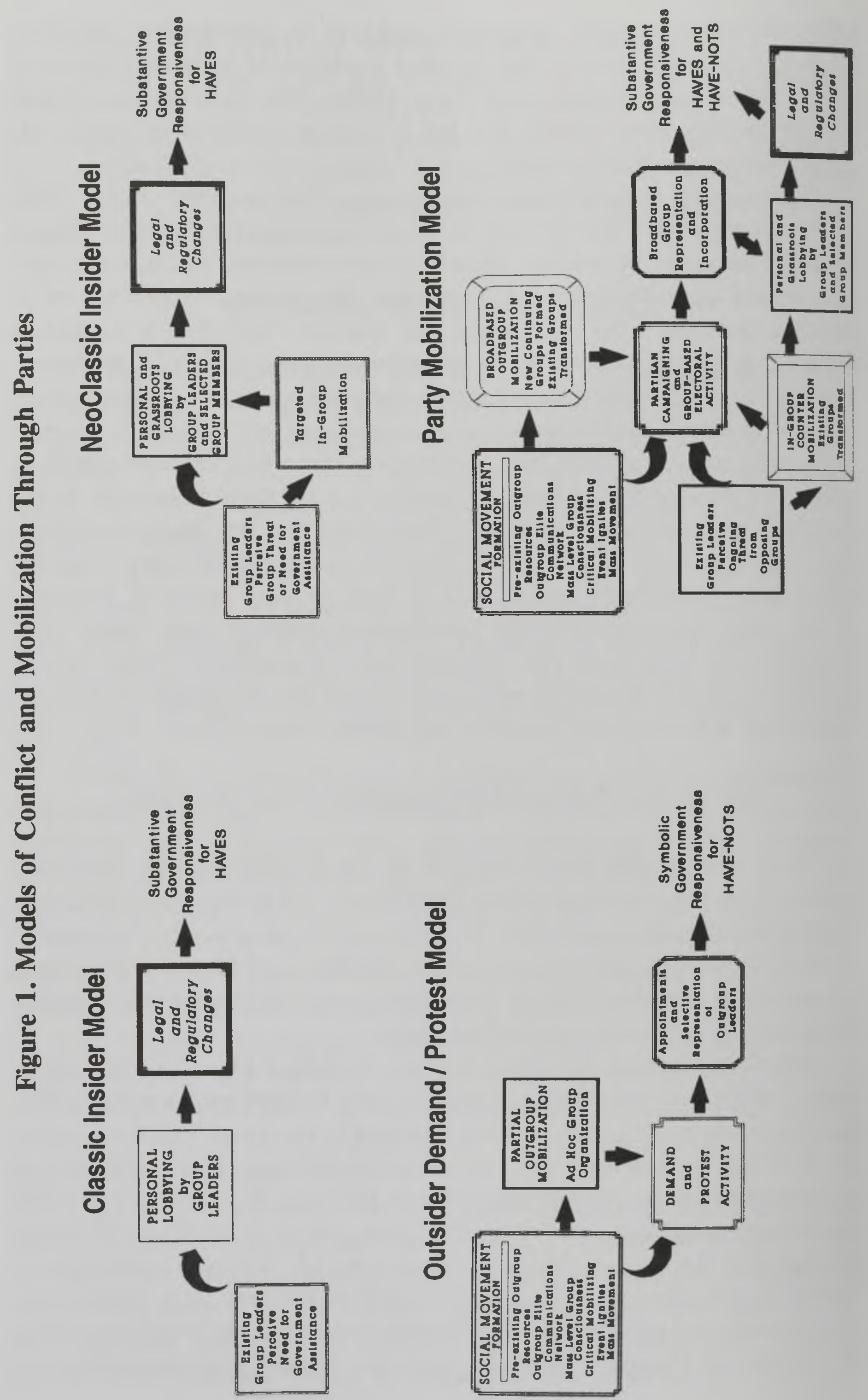
staff), and their clout depends on their personal relationship with key policymakers and their ability to service the internal legislative needs of the legislator-not on the strength of the group or the "rightness" of their position (Ornstein and Elder 1978; Mack 1989).

This model focuses on the "haves," and explains "insider" influence where business interests predominate. While business was poorly organized in the 1950s (Bauer, Pool and Dexter 1972), it nonetheless had considerable political strength because "in the 1950s . . its collective interests were little challenged" (Wilson 1985, 30). This type of influence also was commonly found at the state level: typically, when a state tended to be dominated by a single interest or only a few interests, "that dominant interest was usually business" (Thomas and Hebrenar 1991, 74).

In contrast, some potential interests are drawn from the "have-nots." Their group members do not come from the same background as legislators, and they do not have the money to hire "old Washington hands." Without these tools, political protest becomes the only viable means for effecting change. The "Outsider" demand/protest strategy petitions government from the outside for changes in policy. Marches, sit-ins, protests and demonstrations are the major means of contact with government officials as ad hoc groups organize around specific problems or crises. Notably, pluralism does not account well for the limited options for influence among the have-nots. Instead, pluralists (e.g., Polsby 1983; Hayes 1981) have critiqued groups using these strategies as symptomatic of a degeneration into "mass society" (marked by crazes, fads, etc.) that weakens the party system. Similar to the classic lobbying model, a protest march down Main Street or Constitution Avenue is nonpartisan and directed in equal measure against all government officials. However, it provides less specific information to lawmakers than does insider lobbying.

Mature social movements, in addition to the strategic use of protest, seek primarily to create new elites (Baer and Bositis 1988). This is the electoral or party mobilization strategy. It is this model that dramatically expands the scope of conflict by expanding the interests represented within the parties. To the extent that interest groups work within parties, party factions are broadened and develop greater complexity and boundaries. While social movements also are drawn from the have-nots and employ protests and demonstrations as a strategic tool, they differ in that they pursue distinctly partisan mobilization. As Browning et al. (1989) make clear, those groups seeking incorporation of group members within leadership circles usually obtain greater government responsiveness.

Traditional interests have adapted to these new strategies for influence via a new technique called "grassroots lobbying." This strategy attempts to 
convince legislators that a large segment of their constituents are vocal on an issue. Indeed, "by mobilizing informed local members of the organization-or the employees, retirees, and shareholders of the company-the lobbyists extend, multiply, and reinforce their efforts in every legislative district into which they can reach" (Mack 1989, 124). This is not lobbying by have-nots, but rather an extension of insider lobbying. As Alan Rosenthal put it, "Grass-roots lobbying is an outside game, but it cannot occur independently of the inside one" $(1993,155)$. We term this the neoclassic insider model.

Recent research provides support for the party mobilization model. A major study of interest groups at the state level concluded that they have become "nationalized" (Thomas and Hebrenar 1991). In a study of coalitionbuilding in ten major American cities, Browning et al. (1991) found partisan electoral activity among local interests to be a common and successful strategy. These interests are highly partisan despite the fact that most lobbyists stress their bipartisan approach. For example, while a majority of "insider" Washington lobbyists in a recent survey did not perceive partisanship as "a factor in their work," it clearly was a predominant factor. Heinz et al. $(1993,144)$ found that

Strong Democrats are almost twice as likely to work for liberal groups as to act exclusively for business. Only a handful of Republicans represent liberal groups, while over three-quarters work exclusively for business groups.

These researches suggest that new interests have mobilized and traditional interests have countermobilized on a grassroots as well as a national level. This increases the potential of an expanded scope of conflict to also transform parties in ways consistent with party government theory (Baer and Bositis 1993; Baer 1993).

Which theory provides the best explanation? We cannot determine the answer solely from individual or case studies because any transformation is not likely to be uniform among the states. As Sarah McCally Morehouse found, party organizations do vary among the states in their ability to "control the entry of pressures into the government" $(1981,118)$. A more useful approach is to compare them by means of a "crucial experiment." Instead of picking propositions at random to test, the most rational method, as Arthur Stinchcombe suggests, is to look for "those consequences of our theory whose negation is implied by the alternatives" $(1968,25)$. It is thus pertinent to consider how expanded conflict under the party mobilization model would generate alternate expectations about party and interest transformation. 


\section{Socialization of Conflict: Implications for the Concept of Party Factions}

The concept of faction has been used by various scholars to refer to a party-like interest. V.O. Key (1950) stressed that factions such as those he found in the one-party South provide no real substitute for competitive parties. In contrast, Denise Baer and David Bositis (1988) argue that the social movements of the 1950s and 1960s, in particular the civil rights and women's rights movements, resulted in a special type of change in party factionalism. Baer and Bositis argue that with the decline of the third party alternative, these social movements organized and sought influence within the Democratic and Republican parties. By reforming the parties, social movements become a real antidote to party oligarchy. In order to secure interest representation, factions direct their energies toward staffing the government with their own members. To take advantage of party permeability and achieve representation, factions work to develop new leaders and elect their faction nominees.

Comparative politics scholars distinguish between true factions and tendencies (Beller and Belloni 1978). Tendencies, like Key's earlier notion of faction, are developed around candidates ("electoral tendencies") or temporary ideological wings of the party ("ideological tendencies"). In contrast, true factions develop persistent organizational structures, a certain amount of self-consciousness, an ideological core around which explicit goals can be articulated and pursued, and an internal communications network. Tendencies are less structured, less stable, lack significant mobilization, and are the basis of less enduring competition within a party (Roback and James 1978, 340). As Zareski distinguishes, "only those [tendencies] that endure and develop real organizations and self consciousness qualify as factions" (Zareski 1978, 11).

There is increasing evidence that interests are developing stable factional forms in American parties. Using the conceptional distinction between tendencies and factions, ideological tendencies based on consistent left-right voting ${ }^{2}$ were evident in party conventions as early as 1940 , and consistently found in the pre-reform era from 1940 through 1964 (Munger and Blackhurst 1965). Research finds that at least since the mid-1960s, campaign activists are motivated and mobilized by ideological concerns (Carmines and Stimson 1989). Similarly, greater ideological stability among convention delegates began to appear in 1960 for the Democrats, and in 1964 for the Republicans (Reiter 1980). Costain (1978) finds that about 3040 percent of the final nomination votes in both parties consist of left-right ideological voting. 
Yet, the advent of true factions did not occur until the post-reform era. The American national parties of the 1950s (and earlier) were unique in that they existed without any single continuing inner circle (David, Goldman and Bain 1984, 99). The important dividing line was 1974 (Baer 1993). For example, at the 1972 Democratic Party convention, the black and women's caucuses were primarily forums for speeches, but by 1976, "these two caucuses had established stable leadership structures and sophisticated communications networks" (Pressman 1977-78, 673).

Ralph Goldman (1991) notes that factions in American parties have constituencies internal and external to the party, including the party's "rank and file workers, core party regulars among the voters . . . [and] organized special interests, such as unions, agricultural cooperatives, and ethnic or cultural groupings" (Goldman 1991, 48, 45). Thus, instead of threatening the stability of the party through protracted struggle, factions represent interests and in doing so provide a form of linkage within parties. This happens as citizen activists take on a mediating role whereby "policy cues too subtle to capture public attention . . . become translated into apparently policy conscious electoral behavior" (Carmines and Stimson 1989, 114). While television indeed has transformed the political landscape, groups and group leaders remain influential via what one analyst terms the "two-step media flow of influence" (Popkin 1991). And contrary to conventional wisdom, participation in voluntary groups by citizens is increasing (Baumgartner and Walker 1988). While factions do not perform the functions of parties as far as voters are concerned, factional conflict offers choices for party activists and loosens the grip of internal oligarchy.

\section{Expectations}

These characteristics of true factions provide a theoretical basis to decide when interests have developed an intimate relationship with the parties. If interests are now intimately implicated in the party system-as the party mobilization model would predict-then we would expect to find evidence of true factions as opposed to mere tendencies. By contrast, pluralism would lead us to expect that interest groups would bypass the parties and link citizen interests directly to government officials. Here, we would expect that party leaders and intra-party organizations-especially at the state and local level-would not be highly active in interest groups. Based on Stinchcombe's concept of a "crucial experiment" where theories are tested by comparing opposing expectations, our data analysis strategy will compare five competing expectations: 
-1. Interests will be pervasive among both permanent and temporary party elites and among the state and local parties. [Pluralist negation would locate these only at the national or the temporary party level]

-2. Ideological differences between group members and non-members will be distinct and linked with partisanship. [Pluralist negation would expect that group memberships would not be linked to partisanship]

-3. Groups will exhibit distinct organization and memberships. [Pluralist negation would expect that groups would not be tied to only one party]

-4. Groups will structure flows of information and communication. [Pluralist negation would expect that groups would only control information from elites to non-elites]

-5. Group members will exhibit a group consciousness. [Pluralist negation would find groups not so fundamental in developing views of leaders]

\section{The Party Elite Study}

The Party Elite Study is an ongoing over-time survey of Democratic and Republican party leaders conducted by Denise L. Baer, David A. Bositis, and John S. Jackson III. Each party's officials are sampled immediately after their respective party conventions. The 1988 wave expanded beyond attitudes toward reform and the parties and issue positions to an in-depth exploration of group memberships among party leaders greater than that surveyed in 1980-84 or in 1992. For this reason, the 1988 wave is particularly appropriate to study the relationship of interests to the parties. The study included the universe of the RNC members, both parties' state chairs, and a sample of DNC members, and Democratic and Republican national nominating delegates. Given the extended length of the questionnaire (23 pages), our response rate was a respectable 36 percent. $^{3}$

The sampling approach of the Party Elite Study originally was designed to allow comparisons of different types of party office-holders: presumably delegates differ from national committee members, who also differ from state and county chairs. On measures of ideology, this indeed has been the case (Jackson, Brown and Bositis 1982; Baer and Bositis 1988). However, 
the state and local parties do not exist walled off from local party notables who are also active at other levels. To obtain a national sample of state and local party members, one option is to include only those selected in their capacity as county or state chairs. But this provides only a partial measure of the state and local parties-current local leadership-rather than those who are active in a variety of ways. Convention delegates, for example, are selected through participation in local caucuses and state conventions. All of the RNC members and the vast majority of DNC members are in fact representatives of the state parties (which choose them) to the national party.

From an organizational perspective alone, the increased organizational interdependence of different levels of the party organization suggests caution in using artificial distinctions between party levels that can blind us to the overlapping sets of memberships and interactions between party leaders and activists. For example, about one-third of county chairs also serve on state central committees, all Democratic and Republican state chairs also serve on the National Committees, all Democratic National Committee (DNC) members are also automatic Superdelegates, and many if not most state chairs also serve as the chair of their state delegations to the national nominating conventions.

The empirical question then remains whether the Party Elite Study constitutes a reasonable sample of state and local activists. The sampling decision rule we used was that any county or state chair or national committee member who initially was selected as part of the delegate sample was removed from the delegate sample. Since we included the universe of state chairs (100) and Republican National Committee Members (150, excluding the territories), as well as half of the DNC, our delegate sample artificially excluded increasingly important members of the "permanent" party who were also delegates. The sampling frames per se are thus inappropriate to compare different strata of the parties.

To test whether the full sample from the Party Elite Study reasonably can be used to approximate a national sample of state and local activists, we used the respondent's self-identification as to being primarily active at the national vs. state vs. local levels of the party. We then compared the local party activists to the state and national party activists on various measures of participation in the state and local parties (see Figure 2). The assumption here is that regardless of whether you are an envelope stuffer or a party luminary, those who are meaningfully considered part of the state and local party should have similar patterns of participation. That is, they should attend the same events, and hold the same types of offices. The scores of the local activists are shaded and form a baseline for comparison, as shown in Figure 2. 
Figure 2. Participation in State and Local Parties

Republican Party Elites

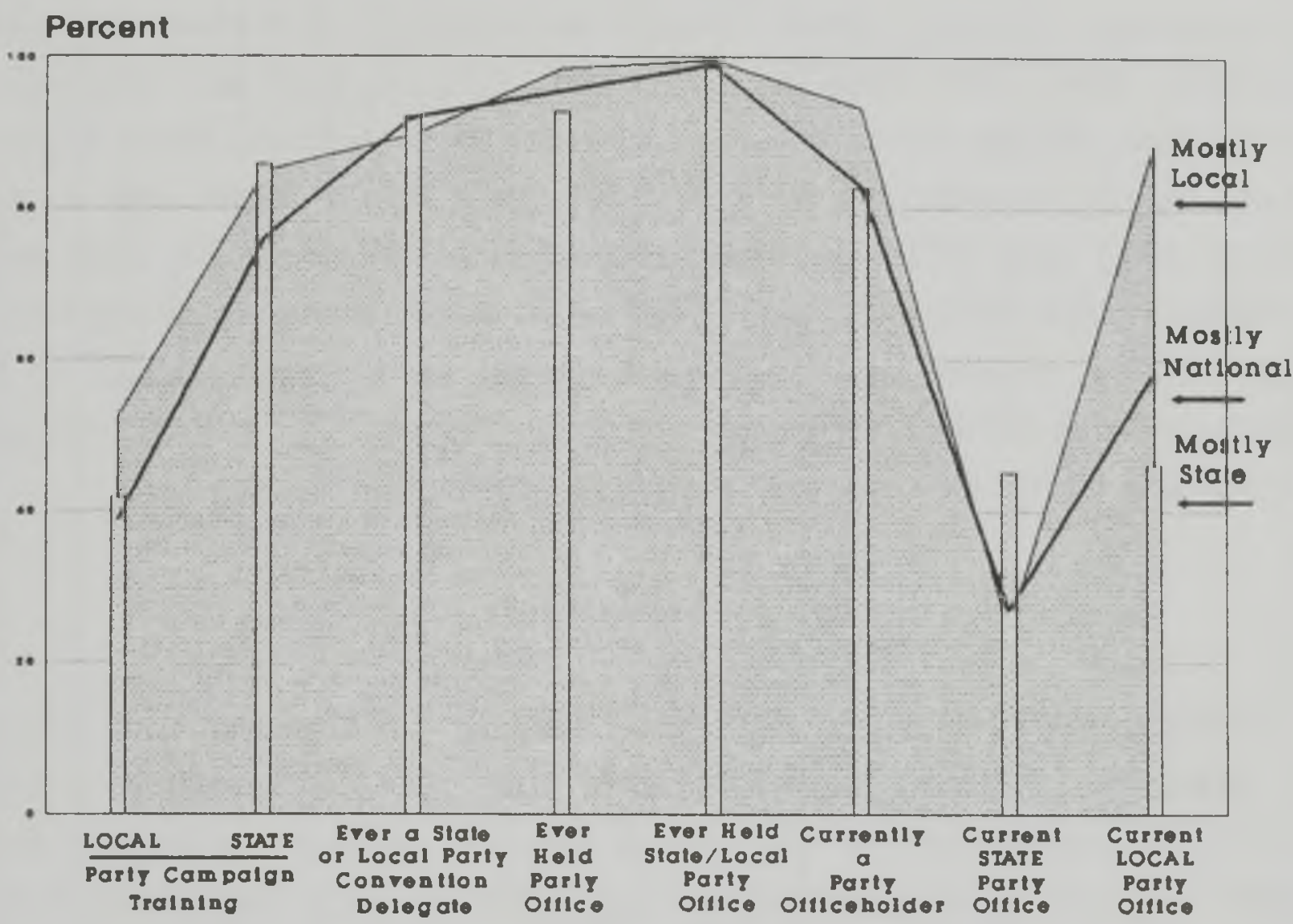

Democratic Party Elites

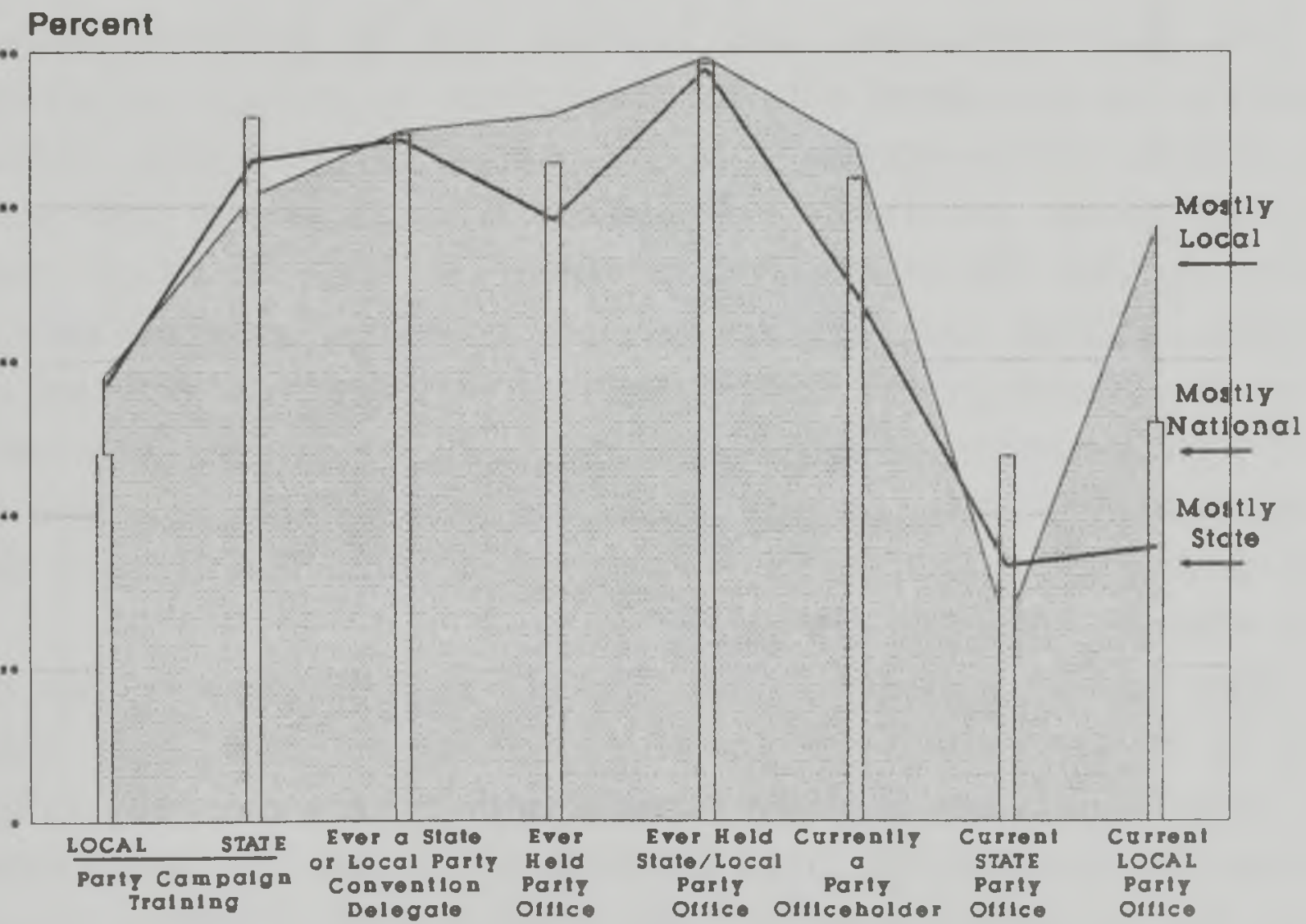


The patterns for both the Democratic and the Republican leaders are remarkably similar both across party and between party levels. Very similar proportions of local, state, and national activists have had state and local party campaign training, been selected as delegates to a state or local party convention, have held state or local party offices, and are currently party officeholders. While those who are active at the national level indeed may be more active in national politics than their fellow state and local party members (and may differ in other important ways as well), they currently participate in the state and local parties, similar to their colleagues. Based on this finding, we decided to group together all Democrats and all Republicans regardless of their original selection criteria. All subsequent analysis will combine party elite samples, unless otherwise noted.

\section{Analysis}

Political interests were measured among Democratic and Republican party elites by inquiring about whether they were a member, activist, or leader in 15 categories of organized interest groups, whether they participated in partisan organizations, and whether they identified themselves as representing group interests in their party work.

\section{Expectation 1: Pervasive Interests}

Our first expectation, that interests will be pervasive among both temporary and permanent elite party members, is strongly supported in the data. For the entire sample, some 87 percent of party elites belong to at least one group. As Table 1 indicates, both temporary and permanent Republican and Democratic party elites, as well as local, state, and nationally oriented members, are found in substantial numbers belonging to at least one interest group. Indeed, across local, state, and national levels of primary party service, at least 80 percent of the party elites from each party belong to at least one category of interest group. This is a high level of group participation that far exceeds the proportion of citizens at the mass levels who participate in groups. ${ }^{4}$

This finding strongly refutes the pluralist expectation that interests active in the party would be found only at the national levels. Certainly, there is some variation in group membership, but this does not differentiate the state and local parties from the national parties. The mean number of groups for the entire sample is 2.68, ranging from 2.08 (for Republicans with national party orientation) to a high of 3.46 (for Democratic national delegates) average group memberships. 


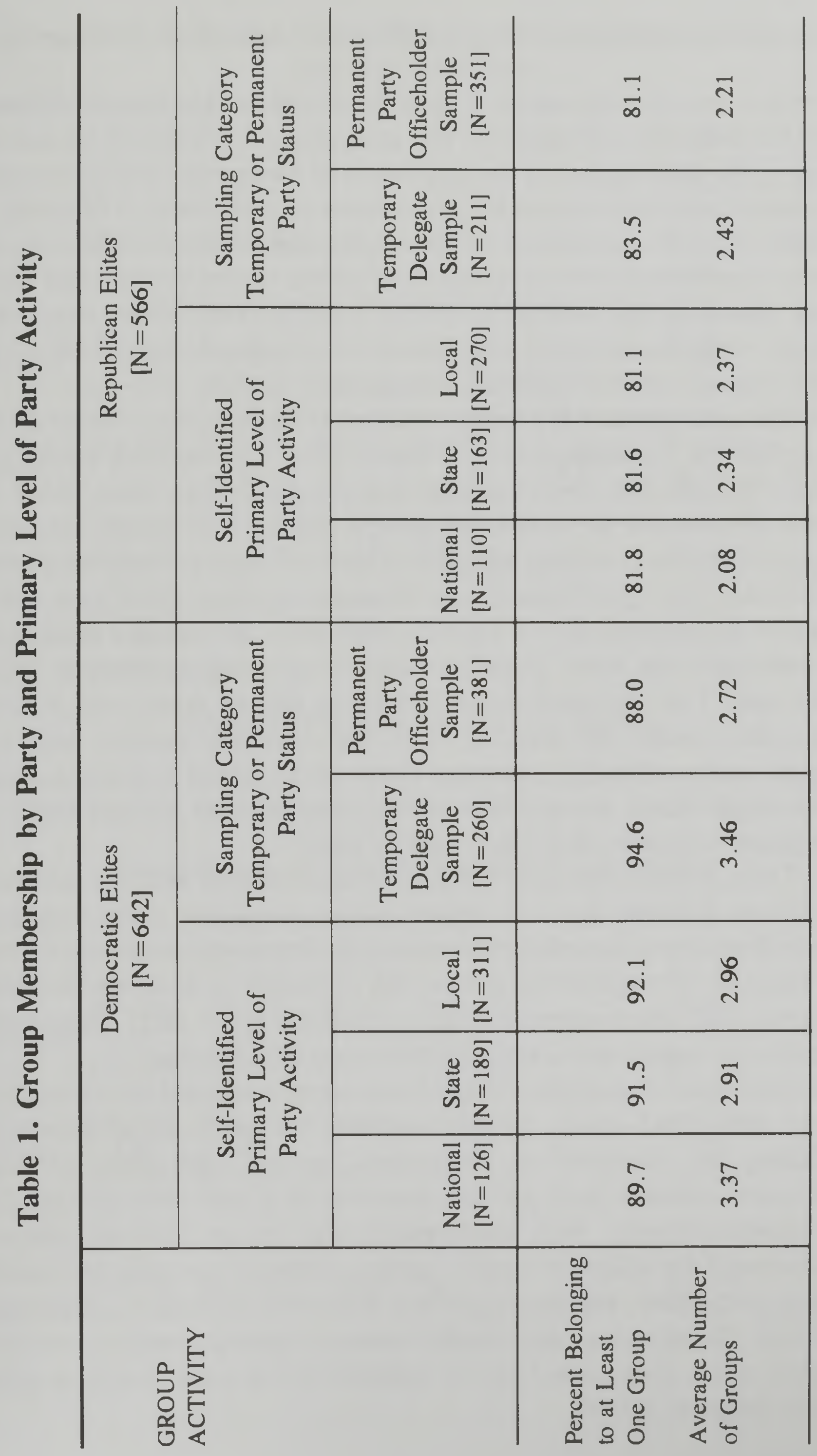




\section{Expectation 2: Ideological Group Differences Accentuate Partisanship}

Our second expectation is that there will be ideological differences between interest group members and non-members which will be tied to the parties. We first compared the proportion of Democrats and the proportion of Republicans who claimed to be a member of each category of group. The difference in the percentage of Democrats and of Republicans was statistically significant for every category of group except professional associations. Based on this national sample of party activists, major categories of groups - with the exception of professional groups-do indeed attract more Democrats or more Republicans among party leaders.

The next question is whether different types of groups provide different constellations of members with differing views on important public policy issues. To test this, we calculated a normed ideology scale based on 5 issues: government aid to minority groups, detente with Russia, government responsibility for providing a good standard of living, government provision of services, and a government raise of minimum wage. Each issue was presented to the respondent as a 7-point Likert scale. We recoded these to make 1 consistently the most liberal response (supporting government involvement) and 7 as the most conservative (or laissez faire), and added the respondent scores. By dividing by 5 , the scale was normed back to the original scale values (i.e., ranging from one to seven) to create a measure of Ideology. ${ }^{5}$ Each group then was compared on their average ideology to non-group members, as a whole and by party.

Table 2 shows the mean ideology of the members and non-members of the fifteen different types of interest groups mentioned in the sample, and breaks them down according to partisanship. In every instance, again except for members of professional groups, the difference in ideology between the members and non-members is highly significant $(\mathrm{p}<.001)$. Interest group membership indeed has a strong relationship with ideology.

Does this relationship still hold true when controlled for by party? We found that it did-even, in this instance, for professional associations. Including the members of professional groups, the mean ideological differences between these partisan members of groups were all statistically significant. Clearly, both partisanship and group ideology shape the environment for different interest groups. Interests not only are pervasive among party elites, but they provide a distinctive ideological grounding for activism. The ideologically similar views of group members provides a context and a core around which cohesive group goals might be pursued within the party system. 


\section{Table 2. Average Issue Ideology of Group Members and Non-Members}

\begin{tabular}{|c|c|c|c|c|c|}
\hline \multicolumn{3}{|c|}{ ALL PARTY ELITES } & \multicolumn{2}{|c|}{ DEMOCRATS ONLY } & REPUBLICANS ONLY \\
\hline Mean I & deology & & Members & Democratic & Members Republican \\
\hline Members & $\begin{array}{c}\text { Non- } \\
\text { Members }\end{array}$ & $\begin{array}{c}t \\
p(t)\end{array}$ & $\begin{array}{l}\text { Mean } \\
\text { Ideology }\end{array}$ & $\begin{array}{l}\text { Members } \\
\text { Percent }\end{array}$ & $\begin{array}{cc}\text { Mean } & \text { Members } \\
\text { Ideology } & \text { Percent }\end{array}$ \\
\hline
\end{tabular}

Groups Proportionately MORE REPUBLICAN in Membership

$\begin{array}{lccccccc}\text { Community } & 3.85 & 3.58 & & 2.95 & 38.1 & 4.69 & 46.9 \\ & {[\mathrm{~N}=508]} & {[\mathrm{N}=696]} & 3.26 * * * & {[\mathrm{~N}=244]} & & {[\mathrm{N}=264]} & \\ \text { Business } & 3.97 & 3.60 & & 3.00 & 32.8 & 4.76 & 45.8 \\ & {[\mathrm{~N}=465]} & {[\mathrm{N}=739]} & 5.55 * * * & {[\mathrm{~N}=207]} & & {[\mathrm{N}=258]} & \\ \text { Veterans } & 4.03 & 3.63 & & 3.14 & 14.7 & 4.78 & 20.1 \\ & {[\mathrm{~N}=207]} & {[\mathrm{N}=997]} & 3.69 * * * & {[\mathrm{~N}=94]} & & {[\mathrm{N}=113]} & \\ \text { Pro-Life } & 4.53 & 3.60 & & 3.24 & 5.9 & 5.09 & 16.7 \\ & {[\mathrm{~N}=132]} & {[\mathrm{N}=1072]} & 7.16 * * * & {[\mathrm{~N}=38]} & & {[\mathrm{N}=94]} & \\ \text { Farm } & 4.21 & 3.63 & & 3.12 & 7.8 & 4.90 & 14.4 \\ & {[\mathrm{~N}=131]} & {[\mathrm{N}=1073]} & 4.38 * * * & {[\mathrm{~N}=50]} & & {[\mathrm{N}=81]} & \\ \text { Evangelical } & 4.67 & 3.64 & & 3.27 & 3.4 & 5.41 & 7.6 \\ & {[\mathrm{~N}=65]} & {[\mathrm{N}=1139]} & 3.67 * * * & {[\mathrm{~N}=22]} & & {[\mathrm{N}=43]} & \end{array}$

Groups NEITHER More Democratic or Republican

$\begin{array}{cccccccc}\text { Professional } & 3.72 & 3.69 & & 2.86 & 30.6 & 4.75 & 29.0 \\ & {[\mathrm{~N}=359]} & {[\mathrm{N}=845]} & .736 & {[\mathrm{~N}=196]} & & {[\mathrm{N}=163]} & \end{array}$

Groups Proportionately MORE DEMOCRATIC in Membership

\begin{tabular}{|c|c|c|c|c|c|c|}
\hline Civil Rights & $\begin{array}{c}2.59 \\
{[\mathrm{~N}=205]}\end{array}$ & $\begin{array}{c}3.92 \\
{[N=999]}\end{array}$ & $-14.88 * * *$ & $\begin{array}{c}2.36 \\
{[N=177]}\end{array}$ & 27.6 & $\begin{array}{c}4.08 \\
{[N=28]}\end{array}$ \\
\hline Environment & $\begin{array}{c}2.98 \\
{[N=222]}\end{array}$ & $\begin{array}{c}3.86 \\
{[N=982]}\end{array}$ & $-8.5 * * *$ & $\begin{array}{c}2.44 \\
{[\mathrm{~N}=160]}\end{array}$ & 25.0 & $\begin{array}{c}4.41 \\
{[N=62]}\end{array}$ \\
\hline Non-Partisan & $\begin{array}{c}2.89 \\
{[N=197]}\end{array}$ & $\begin{array}{c}3.86 \\
{[N=1006]}\end{array}$ & $-9.78 * * *$ & $\begin{array}{c}2.42 \\
{[\mathrm{~N}=1.54]}\end{array}$ & 24.0 & $\begin{array}{c}4.63 \\
{[N=43]}\end{array}$ \\
\hline Feminist & $\begin{array}{c}2.41 \\
{[N=156]}\end{array}$ & $\begin{array}{c}3.89 \\
{[N=1048]}\end{array}$ & -15.42 **⿰㇇⿰亅⿱丿丶丶 & $\begin{array}{c}2.20 \\
{[N=136]}\end{array}$ & 21.2 & $\begin{array}{c}4.00 \\
{[N=20]}\end{array}$ \\
\hline Pro-choice & $\begin{array}{c}2.68 \\
{[N=168]}\end{array}$ & $\begin{array}{c}3.86 \\
{[N=1036]}\end{array}$ & $-11.43^{* * *}$ & $\begin{array}{c}2.29 \\
{[\mathrm{~N}=135]}\end{array}$ & 21.1 & $\begin{array}{c}4.24 \\
{[N=33]}\end{array}$ \\
\hline Education & $\begin{array}{c}2.91 \\
{[N=151]}\end{array}$ & $\begin{array}{c}3.81 \\
{[N=1053]}\end{array}$ & $-7.45 * * *$ & $\begin{array}{c}2.44 \\
{[N=117]}\end{array}$ & 18.3 & $\begin{array}{c}4.59 \\
{[\mathrm{~N}=54]}\end{array}$ \\
\hline Labor & $\begin{array}{c}2.79 \\
{[N=126]}\end{array}$ & $\begin{array}{c}3.80 \\
{[N=1078]}\end{array}$ & $-7.73 * * *$ & $\begin{array}{c}2.58 \\
{[N=113]}\end{array}$ & 17.6 & $\begin{array}{c}4.75 \\
{[N=13]}\end{array}$ \\
\hline Women & $\begin{array}{c}3.31 \\
{[N=139]}\end{array}$ & $\begin{array}{c}3.75 \\
{[N=1065]}\end{array}$ & $-3.3 .5 * * *$ & $\begin{array}{c}2.69 \\
{[N=93]}\end{array}$ & 14.5 & $\begin{array}{c}4.59 \\
{[N=46]}\end{array}$ \\
\hline
\end{tabular}

$* * *=p<.001$ 


\section{Expectation 3: Organizational Structure of Party Factions}

Third, we expect to find groups that exhibit distinct organization and memberships. The question of group memberships was measured by categories of similar types of groups. ${ }^{6}$ All of the examples provided comprise concrete organizations with distinct state and local chapters that provide real opportunities for face-to-face interaction. By our definition of the categories and the examples provided to respondents, these externally organized groups do possess distinct organizations. The question remains, however, whether these groups do have a distinct pattern of organization within the parties.

We first tested this by assuming that if groups exhibit distinct memberships, then individuals should not have random memberships in organizations. Recall that the mean number of groups to which party elites belong is 2.68. As such, we could expect to find overlapping memberships that have partisan links if memberships are not random. For those who claim membership in one category of group, we calculated the proportion who were also members of other groups. The results are shown in Table 3. For this analysis, we included all group members regardless of party affiliation. However, based on the preceding finding that groups differ in their attractiveness to party leaders, we organized the results by party. Table 3 is spatially organized by placing the groups with the greater proportion of Republicans than Democrats (such as Community groups) at the top (and far left) of the table. Following the table from top to bottom (and from left to right), professional groups separate the proportionately more Republican groups from the proportionately more Democratic groups. From there, the groups are proportionately more Democratic, in descending order. The shaded boxes of the table indicate that the overlapping membership between the groups is statistically significant $(p<.05)$. Accordingly, there are strong links between Republican groups with overlapping memberships (shown by the top left hand corner of the table) as well as Democratic groups (the bottom right hand corner of the table).

Overlapping group memberships indicate a partisan basis to group membership. But do these memberships also vary within the parties? To examine this, we compared the group memberships of those party elites who identified themselves either as a member of or as having worked for a distinct intraparty organization. The questionnaire included a list of internal party organizations (a faction under our definition) culled from those party groupings specifically mentioned in party bylaws or else privately organized but operating only within one party (e.g., the Ripon Society). The one exception was the Christian Coalition, which was a strong presence at the 1992 Republican Convention. Since this organization was formed from a 
Table 3. Overlapping Group Membership: Proportion of Group Members Belonging to Other Groups, All Party Elites

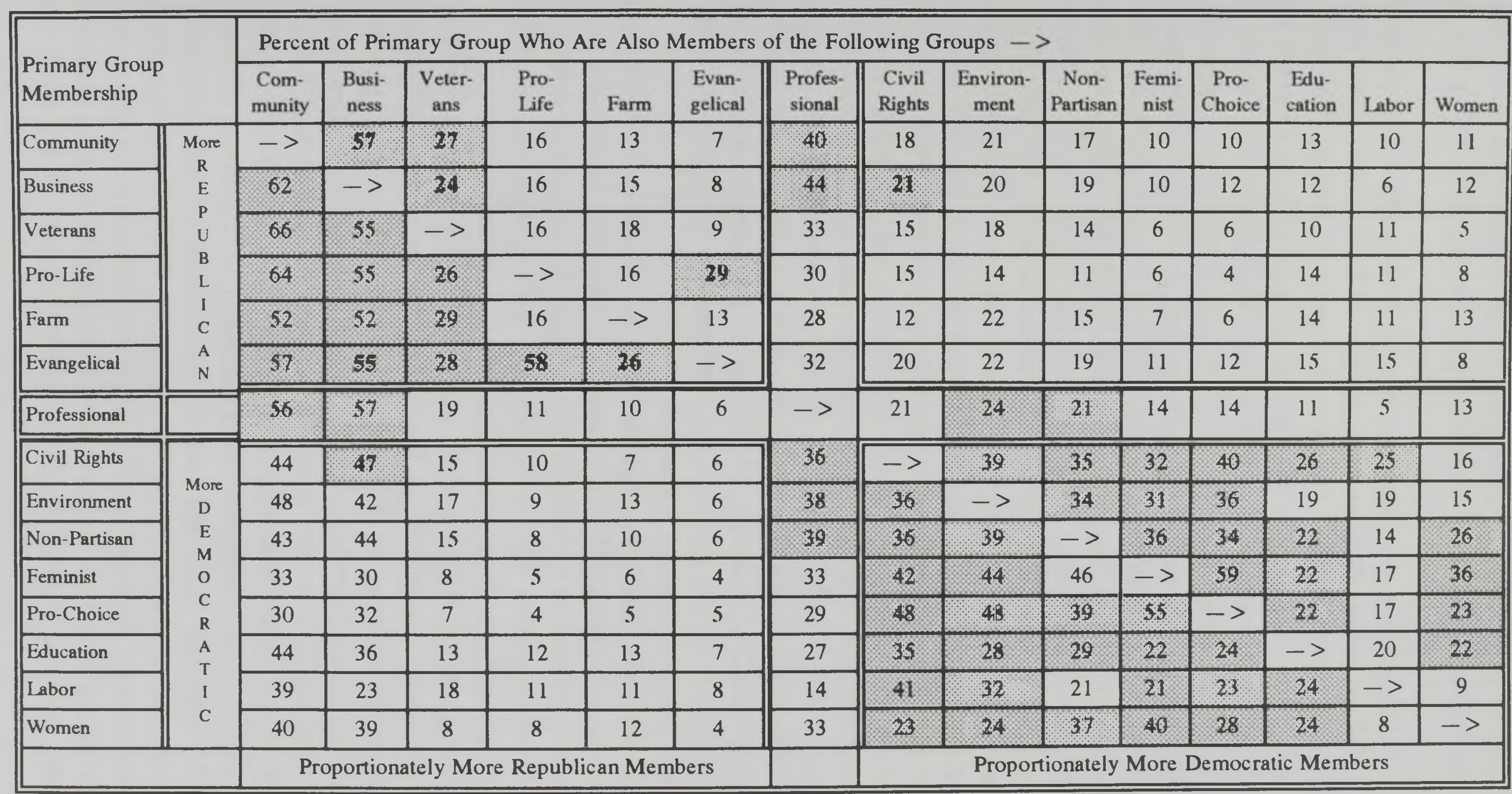

NOTE: Shaded Areas indicate significant proportionally larger memberships in the second group (compared to non-primary group members) at the $p<.05$. 
core group of supporters of 1988 presidential hopeful Pat Robertson, we used a surrogate measure of support for Robertson to identify this protofaction.

Factional activity was common among both party elites. Overall, 78 percent of Republican elites and 74 percent of Democratic elites identified themselves as having worked for at least one party faction. We next compared each party faction in terms of their membership in external interest groups. Figures $3 \mathrm{~A}$ and $3 \mathrm{~B}$ summarize our findings for each party faction (by party) by showing those groups having a significantly higher level of membership in that party faction, compared to non-faction fellow partisans.

Overall, Republican factional conflict was relatively low in 1988. The largest single faction is the Young Republicans (YRs)-almost two-thirds of the 1988 Republican elites. This was followed by the National Federation of Republican Women (NFRW), which included about two out of five Republican elites. The only other faction that comprised at least 10 percent of the sample were those who had worked for the Black Republican Council.

Several of the Republican Party factions included in the survey did not demonstrate any distinctive pattern of external interest group membership among Republicans. These party factions included the conservative College Republicans (CRs) and Republican Seniors, as well as the more moderate Nationalities Council and Hispanic Assembly Republicans. Those who have worked for the CRs comprise 39 percent of the sample, while the Republican Seniors are only 8 percent, the Nationalities Council only 2 percent, and the Hispanic Assembly 9 percent.

The YRs are significantly more likely to belong to Pro-Life organizations, as are Republican Heritage and Black Republican Council members and the proto-faction of Robertson supporters. The Robertson supporters are the most conservative faction within the party, with an overwhelming majority belonging to Evangelical and Pro-Life groups.

By contrast, the Ripon Society members are a whole step more moderate than Robertson supporters. Ripon Society members are significantly more likely to belong to relatively more liberal groups: professional, environmental, and pro-choice and feminist organizations than non-Ripon Society members. However, even this support for the women's movement is relatively low in absolute terms: only one out of four Ripon Republicans belong to pro-choice organizations (compared to 5 percent of non-Ripon members) and less than one out of five Ripon Republicans belong to feminist organizations (compared to 3 percent of non-Ripon Republicans).

Interestingly, factional conflict in the Republican Party is not based on business interests. In fact, business group membership is quite homogeneous among the various Republican Party factions. None of the GOP factions 


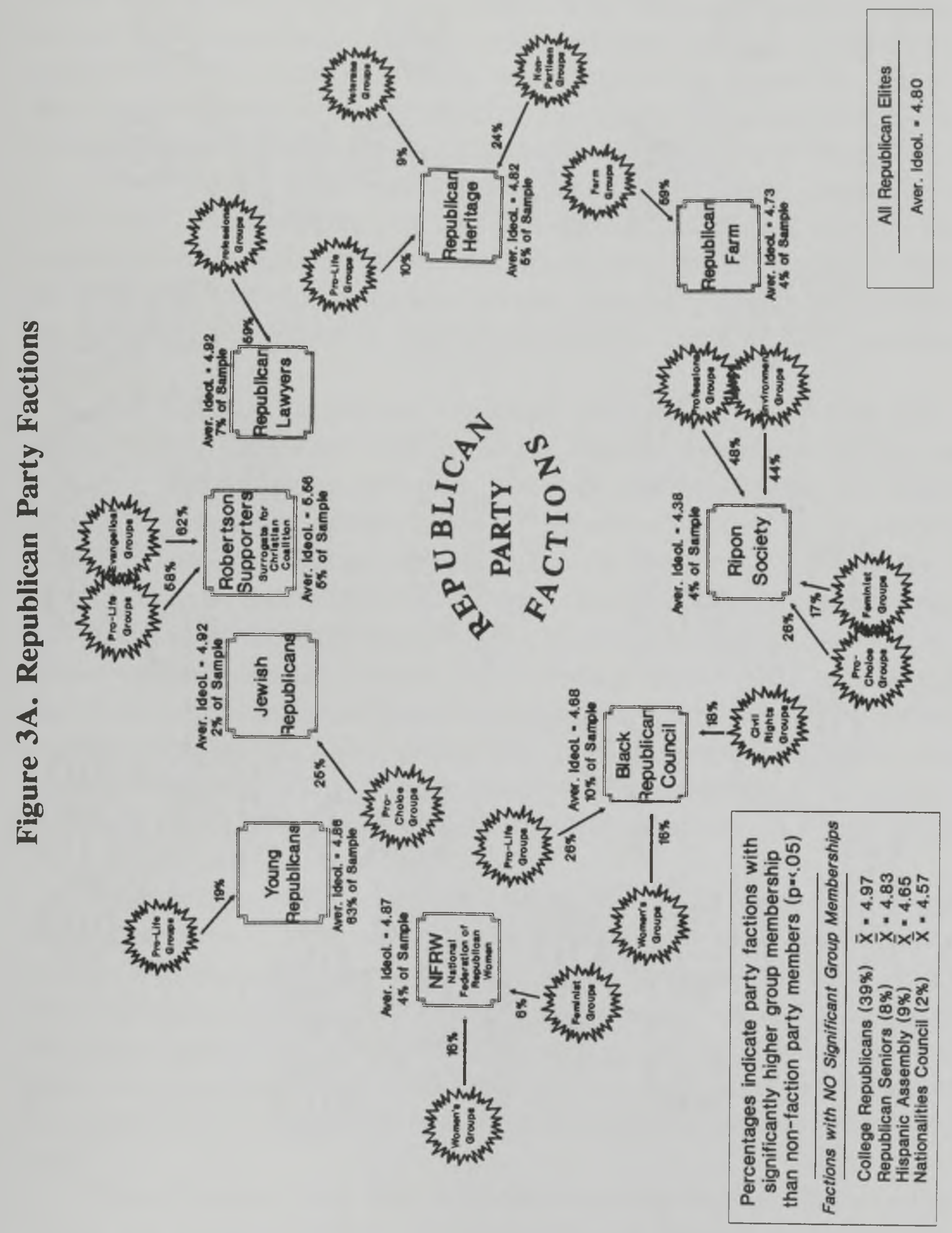


276 | Denise L. Baer and Julie A. Dolan

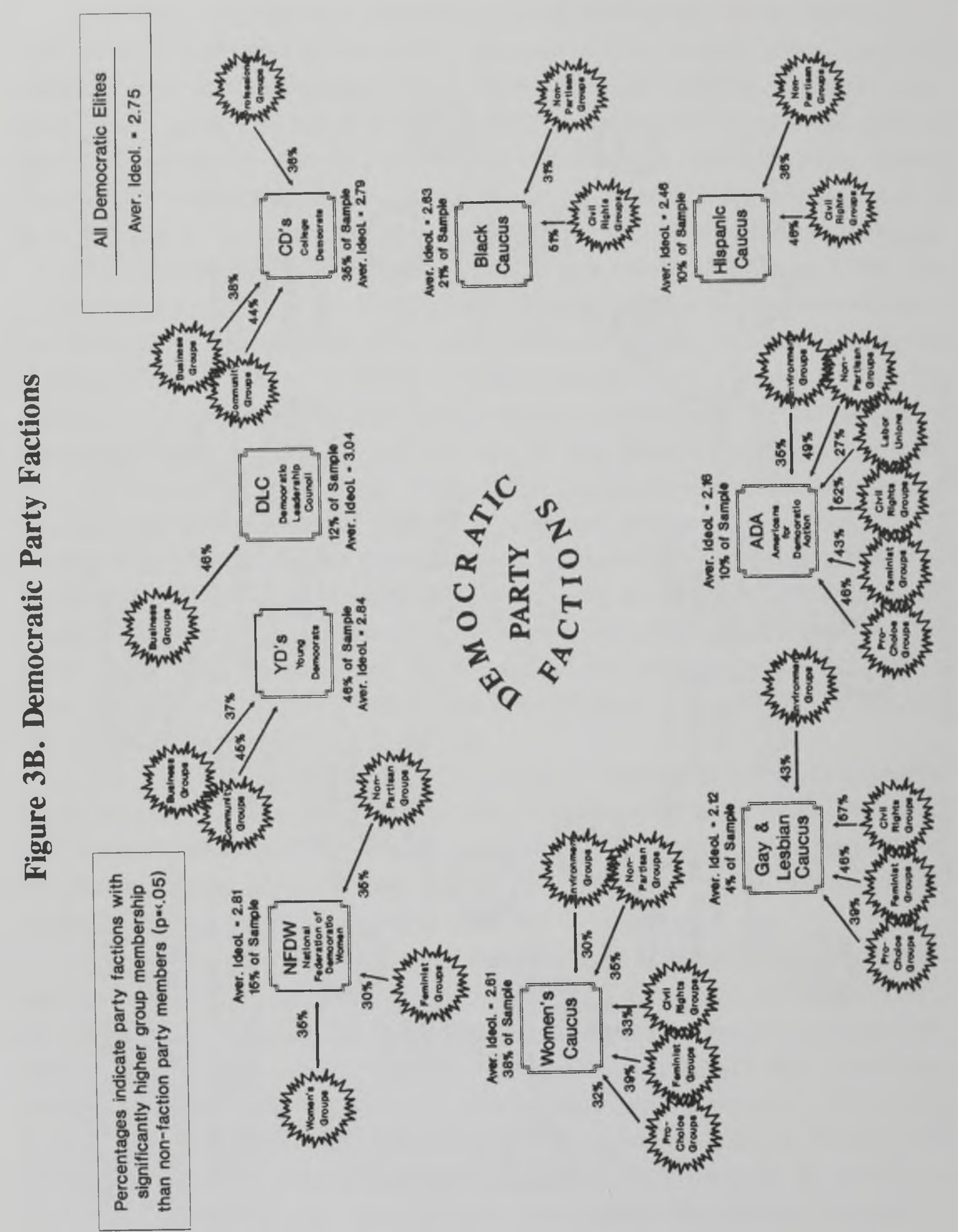


have significantly greater business membership than non-faction members. Only the NFRW stands out as a group with significantly less business group membership-41 percent-compared to 50 percent of non-NFRW Republicans.

Democratic Party factions are both more numerous and more substantial in size. With the singular exception of the Gay and Lesbian Caucus, all of the Democratic Party factions considered here comprise at least 10 percent of the 1988 Democratic elites. In contrast to the Republican Party, the factions incorporate more overlap between interest group memberships, and business interest groups do divide and separate Democratic Party factions.

The Women's Caucus attracts the largest set of liberal interest groups: civil rights, environment, non-partisan, feminist, women's and pro-choice organizational memberships all are significantly higher among those who have worked with the Women's Caucus. Women's Caucus Democrats are significantly less likely to belong to pro-life, veterans' and community groups.

The Democratic groups organized to bring young people into the party-Young Democrats (YDs) and the College Democrats (CDs)-seem to have a conservatizing influence. The YDs are significantly less likely to belong to pro-choice groups-only 17 percent compared to 25 percent of non-YD Democrats. Those who ever have worked for the YDs and the CDs are significantly more likely to be drawn from business group members, as are members of the newest and most conservative Democratic faction, the Democratic Leadership Council (DLC). Nearly half of those associated with the DLC were members of business groups, compared to only 30 percent of non-DLC Democrats. Labor groups are not well represented among contemporary Democratic Party factions, and are overrepresented only among the relatively small ADA Democrats-27 percent compared to 17 percent nonADA Democrats.

Nonpartisan groups (e.g., the League of Women Voters and Common Cause) were found to be significantly more active among both Democratic women's factions and among the more liberal factions-the Black and Hispanic Caucuses and the Americans for Democratic Action (ADA). Half of the Black Caucus Democrats and nearly half of the Hispanic Caucus Democrats were associated with civil rights groups, compared to 22 percent of non-Black Caucus Democrats and 26 percent of non-Hispanic Caucus Democrats.

These findings show that contemporary party factions do indeed differ within the parties. Not only do Democrats and Republicans differ, but so does the group composition of intra-party organizations-essential evidence supporting the development of true factions. 


\section{Expectation 4: Groups and Political Communication}

If party factions provide linkage, we would expect groups that comprise them to provide a key internal communications network among their members both within and outside the parties. To test this, we examined the numbers of party elites who responded that they took suggestions from various groups concerning their party work (self-identified), as well as those who responded that they found specific opinion leaders (e.g. business, religious, minority/ethnic, feminist, union, and women's group leaders) very influential on their decision-making in political matters.

Table 4 lists the primary groups to which individuals belong, as well as the modal category of groups from which they receive suggestions for their party work. There appear to be three "lead" reference groups-business, education, and labor organizations - that dominate political communication among primary group members. First, these three groups monopolize the political suggestions for party work received by party members belonging to their own groups: 54 percent of labor group members, 38 percent of education group members, and 28 percent of business group members cite their own group leaders as offering suggestions.

Second, these three groups provide the most common vehicle of political information among members of other groups. Business leaders are the modal reference group for evangelicals ( 30 percent), pro-lifers ( 28 percent), professionals ( 23 percent), and community group members ( 21 percent). In addition to labor group members, labor leaders are also the modal reference group for civil rights ( 23 percent), feminist (16 percent) and pro-choice group members (13 percent). And education leaders provide the most common source of information and suggestions about party work for veterans and farmers (18 percent each), environmentalists and women's group members (17 percent each), and non-partisan groups (15 percent).

If party elites receive conflicting suggestions and political information, which group(s) do they find most influential? Table 5 shows the top five groups (in percentage) who respond that they find certain opinion leaders very influential in response to a fixed-choice question. Party membership exerts a major influence. For example, substantially more Democratic civil rights group members find minority and ethnic leaders very influential than is true among Republican members. The same is true of labor union members. And substantially more Republican business group members find business leaders very influential than is true of Democratic group members. This is also true among Republican and Democratic evangelical group members. 
Table 4. Group Members Receiving Suggestions from Outside Groups Concerning Their Party Work

Primary Group Membership (Organized by Lead Reference Group)

BUSINESS

Evangelical

Pro-Life

Professional

Community

EDUCATION

Veterans

Farm

Environment

Women

Non-Partisan

LABOR

Civil Rights

Feminist

Pro-Choice
Reference Groups Spontaneously Cited as Offering Suggestions

Percent of

Modal Category Group Members
27.9

30.4

27.9

22.6

21.2

37.7

18.2

17.5

17.0

16.7

14.5

54.0

23.1

15.7

Labor / Feminist

Because of the partisan divide in interest group memberships and factional organization, in the following discussion we focus only on statistically significant differences within the parties. There is a considerable consistency between group memberships and the lead reference group.

In both the Democratic and Republican parties, business group members are significantly more likely to say that they find business leaders very influential than are their fellow partisan non-business group members. Among Democrats, only veterans' group members are more likely to say that they find business leaders very influential.

Evangelical and pro-life members in both parties are significantly more likely to say that they find religious leaders very influential than are nonevangelical and pro-life Members. Similarly, in both parties, labor and educational group members are significantly more likely to cite union leaders as very influential. In the Democratic Party, civil rights members are significantly more likely than non-members to cite both religious and union leaders as very influential. 


\section{Table 5. Top Five Groups Where Members Say Opinion Leaders Are Very Influential}

\begin{tabular}{|c|c|c|c|c|c|c|c|}
\hline \multirow{2}{*}{$\begin{array}{l}\text { Opinion } \\
\text { Leaders Cited } \\
\text { as Very } \\
\text { Influential }\end{array}$} & \multirow{2}{*}{$\begin{array}{l}\text { Primary } \\
\text { Membership } \\
\text { of Top Five } \\
\text { Groups }\end{array}$} & \multicolumn{2}{|c|}{$\begin{array}{c}\text { All } \\
\text { Members }\end{array}$} & \multicolumn{2}{|c|}{$\begin{array}{c}\text { Democratic } \\
\text { Members }\end{array}$} & \multicolumn{2}{|c|}{$\begin{array}{c}\text { Republican } \\
\text { Members }\end{array}$} \\
\hline & & Percent & Chi-Sq & Percent & Chi-Sq & Percent & Chi-Sq \\
\hline \multirow{5}{*}{$\begin{array}{l}\text { Business } \\
\text { Leaders }\end{array}$} & Veterans & 17.8 & $15.72 * * *$ & 12.1 & $7.13^{*}$ & 22.5 & 5.48 \\
\hline & Pro-Life & 17.3 & $7.56^{*}$ & 10.5 & 2.41 & 20.2 & 1.32 \\
\hline & Business & 173 & $55,7^{*} *$ & 123 & $39.06 \% * 7$ & 213 & $11,33 *$ \\
\hline & Evangelical & 17.2 & 2.96 & 9.5 & 1.49 & 20.9 & .92 \\
\hline & Farm & 16.8 & 4.02 & 14.0 & 2.56 & 18.5 & .42 \\
\hline \multirow{5}{*}{$\begin{array}{l}\text { Religious } \\
\text { Leaders }\end{array}$} & Evangelical & 37.8 & $64.88 * *$ & 273 & $14,2 * *$ & 32 & $477^{* *}$ \\
\hline & to & 21 & $58.64 \%$ & 23.8 & $17+1$ & 220 & $38.5 * *$ \\
\hline & Farm & 13.7 & $6.98^{*}$ & 18.0 & $8.82^{*}$ & 11.1 & 1.23 \\
\hline & Business & 10.9 & $11.46^{* *}$ & 9.9 & 5.27 & 11.7 & 4.65 \\
\hline & Civil Rights & 10.9 & $4.74^{*}$ & 11.0 & $6.06^{*}$ & 10.7 & .42 \\
\hline \multirow{5}{*}{$\begin{array}{l}\text { Minority / } \\
\text { Ethnic }\end{array}$} & Civil Rights & 30.8 & $105.3 * * *$ & 34.1 & $63.3 * * *$ & 10.7 & 5.74 \\
\hline & Feminist & 24.0 & $34.52 * * *$ & 25.2 & $13.8 * * *$ & 15.8 & 2.55 \\
\hline & Labor & 21.8 & $15.02 * * *$ & 22.5 & 3.80 & 15.4 & 1.33 \\
\hline & Pro-Choice & 21.6 & $37.5 * * *$ & 25.4 & $19.7 * * *$ & 6.1 & 2.22 \\
\hline & Education & 18.7 & $11.9 * *$ & 17.2 & 1.11 & 23.5 & $14.5^{* * *}$ \\
\hline \multirow{5}{*}{$\begin{array}{l}\text { Feminist } \\
\text { Leaders }\end{array}$} & feotinist & 28.6 & $210,1 * *$ & 28.9 & $812 * 4$ & 26, & $72,4 * x$ \\
\hline & Pra-Choice & 22,2 & $109,4^{*}+1$ & 26.1 & $53,17 * 4$ & 6.1 & $6.81 \%$ \\
\hline & Homen & 16.8 & $37.49 * *=$ & 18 & $1196 *$ & 136 & $3783=4$ \\
\hline & Labor & 16.8 & $43.27^{* * *}$ & 17.9 & $9.3^{* *}$ & 7.7 & 4.40 \\
\hline & Civil Rights & 15.5 & $80.48 * * *$ & 17.9 & $27.2^{* * *}$ & 0 & .72 \\
\hline \multirow{5}{*}{$\begin{array}{l}\text { Union } \\
\text { Leaders }\end{array}$} & Labor & 42 & $2346^{*}$ & 459 & $10811 * 6$ & 64 & $24,4 *$ \\
\hline & Feminist & 19.1 & $51.45 * * *$ & 19.5 & 4.35 & 15.8 & $33.4 * * *$ \\
\hline & Educution & 81 & $40,48 * *$ & 224 & $8.29 \%$ & 5 & 7.69 \\
\hline & Civil Rights & 18.6 & $61.14^{* * *}$ & 21.5 & $8.85^{*}$ & 0 & 1.38 \\
\hline & Pro-Choice & 13.9 & $14.78 * * *$ & 17.4 & .57 & 0 & .45 \\
\hline \multirow{5}{*}{$\begin{array}{l}\text { Women's } \\
\text { Group } \\
\text { Leaders }\end{array}$} & Ethitist & 12 & $1325 * * *$ & 31 & $626+1$ & $3+6$ & $344 x$ \\
\hline & Pro-Choice & 24.0 & $67.98 * * *$ & 28.4 & $38.9 * * *$ & 6.1 & .83 \\
\hline & Labor & 22.4 & $35.65 * * *$ & 23.2 & $10.75 * *$ & 15.4 & 4.39 \\
\hline & Homed & 42 & $31.42 \times 6$ & 24 & $13^{+1}$ & 3.6 & $11.1 \%$ \\
\hline & Civil Rights & 18.4 & $50.00 * * *$ & 20.8 & $18.9^{* * *}$ & 3.6 & .25 \\
\hline
\end{tabular}

NOTE: Shaded Areas indicate where opinion leaders are influential in both parties.

$* \mathrm{p}<.05 * * \mathrm{p}<.01 * * * \mathrm{p}<.001$ 
Despite the partisan cleavage over the women's movement (Freeman 1993), group leaders have considerable influence in both parties. Among both Democrats and Republicans, feminist and women's group leaders are more likely to say that women's leaders are very influential. And Democratic as well as Republican feminist and pro-choice group members are significantly more likely to cite feminist leaders as very influential. Among Democrats, the group membership overlap results in labor and civil rights group members also being significantly more likely to consider feminist leaders as very influential, as is true of pro-choice and civil rights group members concerning women's group leaders.

The largest partisan split concerns minority and ethnic leaders. In the Democratic Party, it is the civil rights, feminist and pro-choice group members who are more likely to cite minority and ethnic leaders as very influential. But among Republicans, it is the members of educational groups who consider minority and ethnic leaders as very influential.

These data demonstrate a strong consistency among group memberships, reference groups, and group leaders for state party elites. If Schattschneider is correct in saying that interests are the "raw materials" of politics, then it is here that parties look for cues in developing their partisan issue "bundles" (Carmines and Stimson 1989).

\section{Expectation 5: Group Membership and Group Consciousness}

The final element that identifies the advent of true party factions is that the group members are self-aware of their own existence. We examined this by analyzing responses-by group - to an open-ended question (placed early in the questionnaire to limit cueing) that asked respondents if there were any groups they feel they represent in their party work, and what that group was.

Table 6 presents the results. The strongest levels of group consciousness and group overlap are found among the more Democratic-oriented groups. Half of the labor union members represent labor interests in their party work. Similarly, nearly half of education group members identify themselves as representing education interests in their party work, nearly half of feminists answered similarly in connection with women's interests, and 38 percent of feminist group members say they represent feminist interests. Feminist interests are also the most common group cited by nonpartisan, pro-choice and environmental group members. About one of every four civil rights group members identify themselves as representing minority or ethnic interests in their party work. Among veteran's group members, 17 percent say they represent minority or ethnic interests. 
Table 6. Self-Identified Group Representation in Party Work

\begin{tabular}{lcr}
$\begin{array}{l}\text { Primary Groups } \\
\text { (Organized by Lead } \\
\text { Reference Group) }\end{array}$ & $\begin{array}{c}\text { Self-Identified Group Representation } \\
\text { Percent }\end{array}$ & $\begin{array}{c}\text { Modal Category } \\
\text { Group Mem }\end{array}$ \\
\hline BUSINESS & BUSINESS & 24.6 \\
Community & Business & 17.4 \\
Evangelical & Business & 17.2 \\
Pro-Life & Business & 14.6 \\
Farm & Business & 16.7 \\
PROFESSIONAL & PROFESSIONAL & 19.2 \\
EDUCATION & EDUCATION & 45.6 \\
CIVIL RIGHTS & MINORITY / ETHNIC & 24.3 \\
Veterans & Minority / Ethnic & 16.7 \\
LABOR & LABOR & 51.9 \\
FEMINIST & FEMINIST & 38.3 \\
Women & Feminist & 44.1 \\
Non-Partisan & Feminist & 35.2 \\
Pro-Choice & Feminist & 33.3 \\
Environment & Feminist & 26.8 \\
& &
\end{tabular}

Business has a dominant role in structuring the interests of Republicantending members. One out of four business group members identify themselves as representing business interests in their party work. Business interests are also the modal category represented by community, evangelical, pro-life, and farm group members. While professional groups are not significantly more Democratic or Republican, about one out of five professional group members say they represent professional group interests in their party work.

These results find a considerable consistency and self-consciousness among group members. Not only are factions active and organized in both parties, interest group members self-consciously seek to represent their particular interests in their collective party work.

\section{An Intimate Connection}

We have found considerable evidence for the development of true factions among contemporary Democratic and Republican party leaders and 
activists at the state and local levels. We have found a link with partisanship, an ideological core, a certain amount of group self-consciousness, and overlapping memberships among kindred groups. While the groups-except for professional organizations-differ proportionately in the numbers of Democratic and Republican leaders who claim membership, we have yet to establish that these groups overlap in such a way that the interest group ideological cores actually comprise a critical mass within other groups. In other words, do the overlapping group memberships cross-cut in such a way that ideology is moderated with the parties or do they instead reinforce and accentuate partisan division?

Part of the difficulty is in defining a "critical mass." We decided to define this as (1) a certain threshold proportion that mutually defined each set of group members, which was also (2) significantly greater than the overall population of the politically active (i.e., the proportion with Democratic and Republican elite samples). We made an arbitrary decision to define the threshold to be at least 20 percent of one set of group members also claiming membership in another category of group. Thus, in a hypothetical example, even if 75 percent of business members claimed to be members of entertainment groups, we did not classify it as a critical mass unless this was significantly more than the general population of the politically active, and a proportion significantly greater than 20 percent of entertainment members were also members of business groups.

The results are graphically portrayed in Figure 4. Each group is depicted by one of three different symbols portraying whether the group's membership among the politically active is proportionately more Democratic in membership, more Republican, or whether there is no difference (the professional organizations). The groups are arrayed from left to right by their average ideology based on the scoring on the normed ideological score. Each double-headed arrow represents a mutually-overlapping critical mass. The result is a "mapping" of the factional bases of the two parties that is remarkably consistent with expectations. The Republican party is comprised of fewer groups, with significant overlaps between business, community, and veteran's groups. The evangelical groups and the pro-life groups are mutually overlapping, but not with any other Republican factions. While proportionately more business members are also members of evangelical organizations, members of evangelical organizations do not comprise a critical mass among business organization members. Given that these data are from 1988 , there is some prospect for future factional conflict between business and the religious right in the Republican Party, should the religious right increase its presence and take fewer cues from business leaders. 


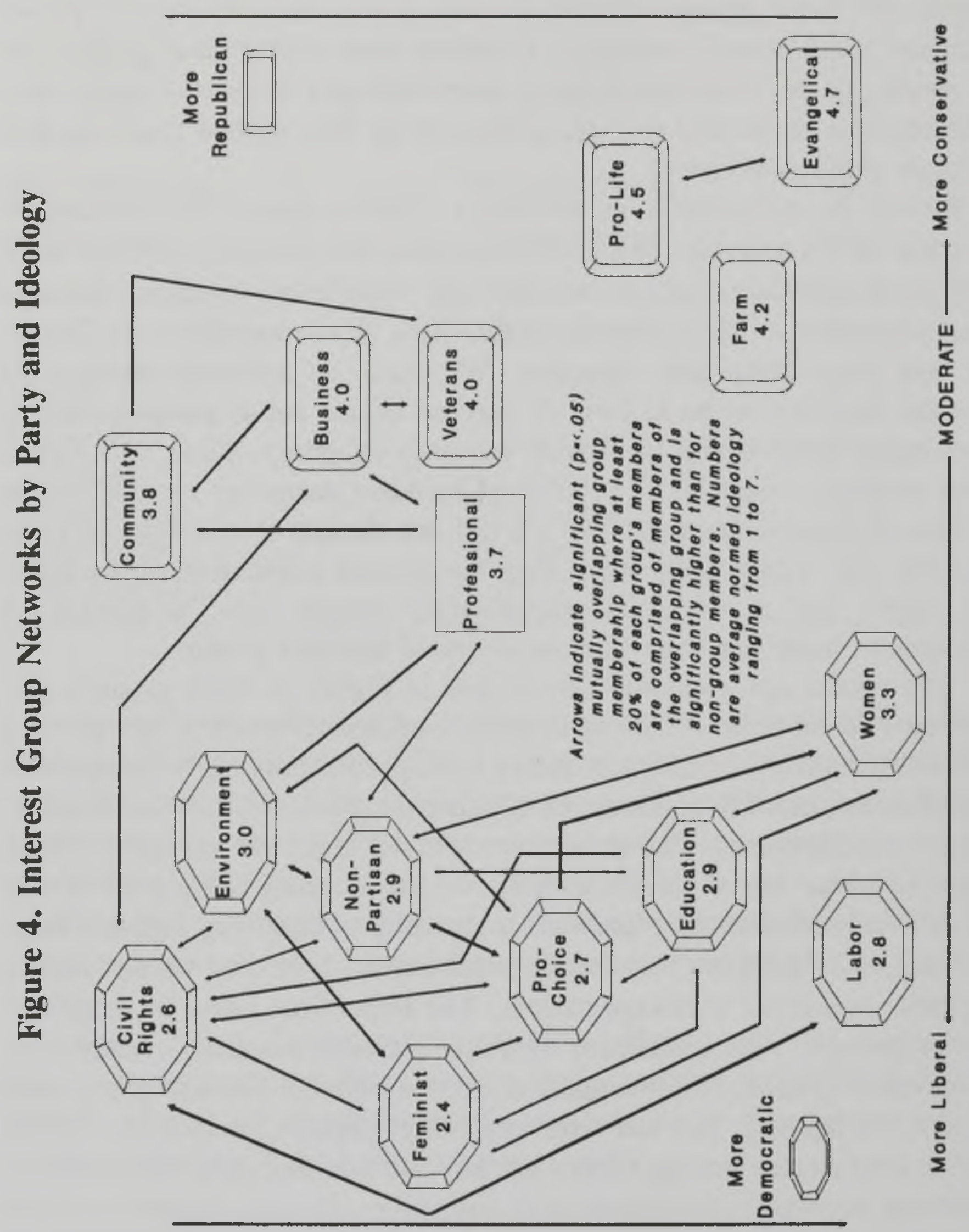


Professional organizations comprise the major organizational linkage between the Republican factional groupings on the right and the Democratic groupings on the left. Only the linkage between business organizations and civil rights organizations comprise a cross-party connecting linkage. This leads us to speculate that business organizations' interest in civil rights provides a moderating influence.

Democratic groups are much more numerous. The connecting linkages are complex, and show considerable overlap. Unlike the Republicans' evangelical/pro-life vs. business/community/veterans split, the diverse Democratic interests do not appear to be so sharply divided. Instead, educational, feminist, pro-choice, women's, civil rights, and labor leaders share significant mutually-overlapping memberships. This finding is consistent with that of Heinz et al. (1993), who find in a study of interest group representatives that Republican elites are more likely to interact in heterogeneous groups than is true of Democratic elites.

\section{Conclusions}

These data show an intimate connection between interests and the parties. Interests that share similar ideological views do work together within a single party. Far from interests working outside the parties, the Democratic and Republican parties provide arenas where interests can work together and collaborate to offer competing policy agendas to the public.

How do strong parties and strong interests co-exist? To answer this, we must revise our theory. Even though party scholars agree that parties as organizations are stronger, political scientists in other subfields continue to debate the decline of party. As evidence, an increasingly narrow interest group strength is viewed as prima facie proof that parties as institutions are in disarray. In looking at the 1992 election, for example, Thomas Patterson charges that "Disorganization is the hallmark" of a presidential election system dominated by "entrepreneurial candidates" and "groups and elites joined together solely for the election" (1993, 105). Quoting V.O. Key's critique of unstable, personality-based "factions" in a perpetual "state of nature" in the South, Patterson differentiates these new groupings from the "loyal armies" of the past by stressing that "There is no name associated with these factions, no continuing core of supporters, and typically the issues that dominate one campaign are unlike those emphasized in the previous campaign" $(1993,106)$.

Some forty plus years after Key's insightful analysis, we found a very different "state of nature" among a national sample of state party elites. In contrast to Key, who saw only floating, personality-based "factions" in 
the one-party South of the early post-New Deal era, we found that among American parties, just as in other Western parties, there is a useful distinction to be made between tendencies (Key's unstable factions) and true factions. True factions are stable organizational forms, not a chaotic state of nature, that provide linkage between elites and non-elites through distinctive patterns of interest group membership. Data may be inconvenient, but the advent of true factions in the post-reform institutionalized party system is a datum that our party theory must now take into account.

This paper does not directly test whether parties and interests-both of which we know from other research are now considerably stronger-are equally strong. But by exploring the intersection between interest group members and party elites, we offer evidence that interests and parties are complementary, rather than opposing, linkage institutions. Consistent with the party government model, which assumes an intimate relationship between party responsibility and strong interests, the parties represent different social groups and interests and are able to offer real alternatives to voters precisely because different interests take different positions on a liberalconservative dimension. The fact that interests are so strongly intertwined with state and local parties provides disconfirmation of the myth that strong interests somehow lead to decline at the party grassroots. In contrast, we found interests pervasive among both Democratic and Republican party members, thereby offering evidence that party elites are linked to non-elites through their role in representing these various interests.

Conflict now is brokered in complex ways by the parties and true party factions that political scientists need to confront. In contrast to Patterson's depressing conclusion that the system is marked by "tenuous relationships" that "put an extraordinary burden on the voter, " we find that strong interests and strong parties are complementary and provide real forms of linkage that reduce the information costs of voters.

Ironically, we think a careful reading of party history would conclude that disorganization, rather than "loyal armies," probably better described the traditional parties favored by restorationist critics of reform. Consider, for example, what the bandwagon effect in pre-reform conventions really represented in practice. Instead of a deliberative peer review process, support for likely winners increased rapidly based solely on expectations as delegates joined the "bandwagon." As Nelson Polsby (1960) describes the process, crowd effects-rather than structure, organization, or real group interests-predominate. Delegates are alert to change their expectations to conform to the "latest information which may be nothing more substantial than a rumor, which quickly takes on the status of a self-fulfilling prophecy, as delegates stampede in response to expectations-quickly realized-about 
how other delegates will respond" (Polsby 1960, 617). It takes a considerable leap of the imagination to view "rumors" and "stampedes" as the hallmark of an organized "army" of loyal partisans.

Data may be inconvenient, but the myth of party decline-with its glorification of a non-existent past-is placing an extraordinary burden on the ability of commentators and scholars to understand the contemporary system.

\section{NOTES}

'Critics of theories of voting behavior (e.g., Pomper 1976; Texeira 1989) have, for example, stressed that the $1950 \mathrm{~s}$ was a unique era in American politics, and therefore not adequate for development of a general theory of voting.

${ }^{2}$ While we are comparing tendencies vs. true factions, this ideological voting is also distinct from a "winner support bloc" which traditional party theory hypothesized not only primarily motivated party elites, but also comprised the most desirable motivation for elites (Polsby 1960).

${ }^{3}$ This response rate differs from our earlier surveys, where we usually obtain around a $50 \%$ response rate. However, as Miller, Jewell and Sigelman (1987) point out, given a complex survey instrument and the competition from other competing surveys of delegates at conventions, this is not surprising.

${ }^{4}$ Using a much more expansive definition of group membership that we included in the Party Elite Study, Schlozman and her associates found from 45 to $79 \%$ of citizens participated in groups (Schlozman 1994; see also Baumgartner and Walker 1988). Compared to these studies, we used the traditional measure of counting only categories of groups rather than the number of groups within categories, and we also did not inquire about leisure and hobby organizations-a large category included in the mass-level studies.

'The scale was tested using reliability analysis and was found to be quite reliable with an Alpha score of .84 .

${ }^{6}$ Each category included several examples to help the respondent identify the relevant categories: Women's Organizations were exemplified as the Business and Professional Women or the American Association of University Women, while Feminist Groups were represented by the National Organization for Women and the National Women's Political Caucus. NonPartisan groups included Common Cause and the League of Women Voters while Community Service Groups included the Rotary Club, Kiwanis, and Elks, and Veterans' Groups included the Veterans of Foreign Wars and the American Legion. Professional Organizations included the American Bar Association and the American Medical Association while Business Organizations were typified by the Chamber of Commerce and the National Association of Manufacturers. Farm Groups included the Farm Bureau and the Grange. Civil Rights Groups were exemplified by the National Association for the Advancement of Colored People, Operation Push, Southern Christian Leadership Conference, and the Urban League, and Pro-Choice Groups include the National Abortion Rights Action League and Planned Parenthood. Labor groups were typified by the AFL-CIO, and the United Auto Workers. Environmental groups included the Sierra Club and the Audobon Society. Education groups included the National Education Association and the American Federation of Teachers. Anti-Abortion groups included BirthRight and other Right-to-Life groups, while Evangelical groups included the Moral Majority and the Christian Voice. 


\section{REFERENCES}

Baer, Denise L. 1993. Who Has the Body? Institutionalization and Theories of Party Organization. American Review of Politics 14: 1-32.

and David A. Bositis. 1988. Elite Cadres and Party Coalitions: Representing the Public in Party Politics. Westport: Greenwood Press.

and David A. Bositis. 1993. Politics and Linkage in a Democratic Society. Englewood Cliffs: Prentice Hall.

Banfield, Edward C. 1980. Party 'Reform' in Retrospect. In Robert M. Goldwin, ed., Political Parties in the Eighties. Washington, DC: American Enterprise Institute.

Bauer, Raymond, Ithiel de Sola Pool, and Lewis Anthony Dexter. 1972. American Business and Public Policy. Chicago: Aldine.

Baumgartner, Frank R. and Jack L. Walker. 1988. Survey Research and Membership in Voluntary Associations. American Journal of Political Science 32: 908-28.

Belloni, Frank, and Dennis C. Beller, eds. 1978. Faction Politics: Political Parties and Factionalism in Comparative Perspective. Santa Barbara: ABC-Clio.

Berry, Jeffrey M. 1989. Subgovernments, Issue Networks, and Political Conflict. In Richard A. Harris and Sidney M. Milkis, eds., Remaking American Politics. Boulder: Westview Press.

Berry, Jeffrey M. 1993. Citizen Groups and the Changing Nature of Interest Group Politics in America. The Annals of the American Academy of Political and Social Science 528: 30-41.

Browning, Rufus P., Dale Rogers Marshall, and David H. Tabb, eds. 1990. Racial Politics in American Cities. New York: Longman.

Cigler, Allan J., and Burdett Loomis, eds. 1991. Interest Group Politics, third edition. Washington, DC: Congressional Quarterly Press.

Costain, Anne. 1978. An Analysis of Voting in American National Nominating Conventions, 19401976. American Politics Quarterly 6: 95-120.

Cotter, Cornelius P., James L. Gibson, John F. Bibby, and Robert J. Huckshorn. 1984. Party Organizations in American Politics. New York: Praeger.

Crotty, William J., ed. 1986. Political Parties in Local Areas. Knoxville: University of Tennessee Press.

David, Paul T., Ralph M. Goldman, and Richard C. Bain. 1960. The Politics of National Nominating Conventions. Washington, DC: Brookings.

Duverger, Maurice. 1954. Political Parties. New York: John Wiley \& Sons, Inc.

Eldersveld, Samuel. 1986. The Party Activist in Detroit and Los Angeles: A Longitudinal View, 1956-1980. In William J. Crotty, ed., Political Parties in Local Areas. Knoxville: University of Tennessee Press.

1986. Research on Local Party Activists and Organizations: Major Questions for the Agenda. Paper presented at annual meeting of the American Political Science Association, Washington, DC.

Freeman, Jo. 1993. Women at the 1992 Democratic and Republican Conventions. P.S.: Politics and Political Science 26:

Goldman, Ralph. 1991. The Nominating Process: Factionalism as a Force for Democratization. Midsouth Political Science Journal 12: 42-64.

Hayes, Michael T. 1983. Interest Groups: Pluralism or Mass Society? In Allan J. Cigler and Burdett A. Loomis, eds., Interest Group Politics. Washington, DC: Congressional Quarterly Press. Heinz, John P., Edward O. Laumann, Robert L. Nelson, and Robert H. Salisbury. 1993. The Hollow Core: Private Interests in National Policy Making. Cambridge: Harvard University Press.

Herrnson, Paul. 1990. Reemergent National Party Organizations. In L. Sandy Maisel, ed., The Parties Respond: Changes in the American Party System. Boulder: Westview Press. 
Jackson, John S. III, Barbara Leavitt Brown, and David A. Bositis. 1982. Herbert McClosky and Friends Revisited: 1980 Democratic and Republican Elites Compared to the Mass Public. American Politics Quarterly 10: 158-180.

Key, V.O. 1950. Southem Politics in State and Nation. New York: Alfred A. Knopf, Inc.

Mack, Charles S. 1989. Lobbying and Government Relations. New York: Quorum Books.

Miller, Penny M., Malcolm E. Jewell, and Lee Sigelman. 1987. Reconsidering a Typology of Incentives Among Campaign Activists. Western Political Quarterly 40: 519-526.

Morehouse, Sarah McCally. 1981. State Politics, Parties and Policy. New York: Holt, Rinehart, and Winston.

Mundo, Philip A. 1992. Interest Groups: Cases and Characteristics. Chicago: Nelson-Hall.

Munger, F. and J. Blackhurst. 1965. Factionalism in the National Conventions, 1940-1964. Joumal of Politics 27: 375-94.

Ornstein, Norman J., and Shirley Elder. 1978. Interest Groups, Lobbying, and Policymaking. Washington, DC: Congressional Quarterly Press.

Patterson, Thomas E. 1993. Let the Press Be the Press: Principles of Campaign Reform. In 1-800PRESIDENT: The Report of the Twentieth Century Fund Task Force on Television and the Campaign of 1992. New York: Twentieth Century Press.

Petracca, Mark P., ed. 1992. The Politics of Interests: Interest Groups Transformed. Boulder: Westview Press.

Polsby, Nelson W. 1960. Decision-making at the National Conventions. Western Political Quarterly 13: 609-19.

. 1983. Consequences of Party Reform. New York: Oxford University Press.

Popkin, Samuel L. 1991. The Reasoning Voter: Communication and Persuasion in Presidential Campaigns. Chicago: University of Chicago Press.

Pressman, Jeffrey. 1977-78. Groups and Group Caucuses. Political Science Quarterly 92: 673-82.

Reiter, Howard L. 1980. Party Factionalism: National Conventions in the New Era. American Politics Quarterly 8: 303-18.

Rosenthal, Alan. 1993. The Third House: Lobbyists and Lobbying in the States. Washington, DC: Congressional Quarterly Press.

Schlozman, Kay Lehman. 1994. Voluntary Organizations in Politics: Who Gets Involved? In William Crotty, Mildred A. Schwartz and John C. Green, eds., Representing Interests and Interest Group Representation. Washington, DC: University Press of America and The Ray C. Bliss Institute of Applied Politics.

Stinchcombe, Arthur. 1968. Constructing Social Theories. New York: Harcourt, Brace and World. Thurber, James. 1991. Dynamics of Policy Subsystems in American Politics. In Allan J. Cigler and Burdett Loomis, eds., Interest Group Politics, third. ed. Washington, DC: Congressional Quarterly Press.

Wilson, Graham K. 1985. Business and Politics. Chatham, NJ: Chatham House. 